\title{
KARAKTERISTIK ADSORPSI TEMBAGA (II) PADA HUMIN DALAM MEDIUM AIR TAWAR
}

\author{
Roy Andreas ${ }^{1}$, Narsito ${ }^{2}$, Sri Noegrohati ${ }^{3}$ \\ ${ }^{1}$ Jurusan Kimia, Program Sarjana MIPA Unsoed Purwokerto \\ ${ }^{2}$ Jurusan Kimia, FMIPA UGM, Yogyakarta \\ ${ }^{3}$ Fakultas Farmasi, UGM, Yogyakarta
}

\begin{abstract}
Although humic substances consist mosly of humin (65\%), however its characteristic in $\mathrm{Cu}$ (II) odsorption is not yet clearly revealed. In this work, humin was isolated from peat soil of west Kalimantan, purified and then interacted with $\mathrm{Cu}$ (II). The purity of isolated humin was determined by its ash content. The funtional group in this purified humin was characterized qualitatively by FTIR and quantitatively by titration. Study on the solubility of $\mathrm{Cu}$ (II) in freshwater was carried out at $\mathrm{pH}$ from 2-12 in the presence and without purified humin. To obtain adsorption kinetic parameters of $\mathrm{Cu}(\mathrm{II})$ on humin in freshwater, study based on Langmuir-Hinshelwood was carried out, while for its thermodinamics parameters, a study based on Langmuir and Freundlich were employed.

The ash content of purified humin was $1,58 \%(\mathrm{w} / \mathrm{w})$, it showed that the humin was in pure condition. The active fungtional group identified humin were $-\mathrm{COOH}\left(1700 \mathrm{~cm}^{-1}\right)$ $115 \mathrm{cmol} / \mathrm{kg}$ and $-\mathrm{OH}$ fenolic $\left(3421,5 \mathrm{~cm}^{-1}\right) 562 \mathrm{cmol} / \mathrm{kg}$. At $2<\mathrm{pH}<5$ was in $\mathrm{Cu}$ (II) and $\left[\mathrm{Cu}\left(\mathrm{H}_{2} \mathrm{O}\right)_{4}\right]^{2+}$ which soluble in water, at $6<\mathrm{pH}<7$ part of the soluble $\mathrm{Cu}(\mathrm{II})$ precipitated as $\mathrm{Cu}(\mathrm{OH})_{2}$ while at $\mathrm{pH}>7$ all of $\mathrm{Cu}(\mathrm{II})$ was precipitated as $\mathrm{Cu}(\mathrm{OH})_{2}$. The rate constant for $\mathrm{Cu}$ (II) in freshwater medium were $2,7 \times 10^{-3} \mathrm{~S}^{-1}$ and $0,6 \times 10^{-3} \mathrm{~S}^{-1}$. The obtained curve fitting of langmuir and freundlich adsorption showed that Langmuir model fit better than Freundlich, indicated that the adsorption reaction are of monolayer. The adsorption capacities of $\mathrm{Cu}(\mathrm{II})$ on humin in freshwater was $3,033 \times 10^{-4} \mathrm{~mol} / \mathrm{g}$
\end{abstract}

Keywords : $C u(I I)$, adsorption, humin, freshwater

\section{PENDAHULUAN}

Menurut Stumm dan Morgan (1996), Hampir semua kation di air terdapat dalam keadaan terhidrasi; ikatan dengan spesies lain dianggap merupakan reaksi pertukaran spesies tersebut dengan molekul air, misalnya membentuk bahan kompleks. Kebanyakan ion logam mempunyai bilangan koordinasi lebih dari satu. Kompleks khelat terbentuk bila 2 atau lebih posisi koordinasi ditempati oleh atom donor ligan yang sama membentuk struktur cincin internal, sehingga lebih stabil (Sunarsih, 2005).

Bahan organik di lingkungan perairan terdapat dalam keadaan terlarut dalam air dan dalam keadaan terikat sebagai bagian dari sedimen. Secara garis besar bahan organik di perairan dapat dibedakan menjadi 2 jenis yaitu bahan yang belum terhumufikasi dan telah terhumufikasi. Bahan organik yang belum terhumufikasi meliputi bahan-bahan penyusun tanaman atau organisme lain yang mempunyai sifat-sifat spesifik, misalnya karbohidrat, asam amino, protein, lipida, asam-asam nukleat dan lignin, sedangkan bahan organik yang telah terhumufikasi dikenal sebagai humus atau bahan humat yang merupakan hasil akhir dari dekomposisi dan degradasi bahan tanaman dalam tanah (Tan, 1998), berupa zat yang bersifat amorf, koloidal, berwarna kuning hingga coklat kehitaman dan memiliki berat molekul relatif tinggi (Tan, 1993 dan 1994). 
Bahan humat, sebagai hasil dekomposisi organisme, merupakan campuran sejumLah polimer organik dengan gugus hidrofobik dan gugus hidrofilik, mempunyai sifat polielektrolit dan polifungsional (Mota,1996 dan Caroli,1996). Sifat hidrofilik terutama diberikan oleh gugus karboksilat $-\mathrm{COOH}$ dan $-\mathrm{OH}$ fenolat.

Humin didefinisikan sebagai bahan organik dalam tanah yang berikatan dengan material anorganik terutama mineral-mineral aluminosilikat atau lempung dan membentuk suatu kumpulan komposit organo-mineral yang kuat. Humin merupakan fraksi bahan humat yang tidak larut dalam cairan pada berbagai nilai $\mathrm{pH}$ (Stevenson, 1994). Humin diperoleh sebagai residu padat yang tersisa sesudah pemisahan sampel humus secara ekstraksi pada suasana basa. Humin juga dideskripsikan sebagai suatu polimer dengan berat molekul tinggi (Stevenson, 1982) atau dapat berupa kumpulan lignoprotein (Kalmari,1982).

\section{METODE PENELITIAN}

\section{Isolasi dan pemurnian humin}

Humin diisolasi dari tanah gambut yang berasal dari Desa Siantan Hulu, Kec. Pontianak Utara, Kodya Pontianak Kalimantan Barat. Metoda isolasi yang digunakan adalah metode ekstraksi alkali.

\section{Karakterisasi humin}

Penetapan kadar abu humin dilakukan dengan memanaskan $50 \mathrm{mg}$ humin dalam tungku (furnace) hingga temperatur $750^{\circ} \mathrm{C}$ selama 4 jam, berat sampel awal sebelum dan sesudah dipanaskan dicatat. Penentuan gugus fungsional humin dengan FTIR.

Penetapan kandungan keasaman total dilakukan dengan cara menambahkan $20 \mathrm{~mL}$ larutan jenuh $\mathrm{Ba}(\mathrm{OH})_{2}$ kedalam $100 \mathrm{mg}$ humin lalu dishaker selama 24 jam pada temperatur kamar. Dilakukan hal yang sama untuk blangko. Suspensi yang terbentuk disaring menggunakan kertas saring whatman 42 dan residu dibilas dengan air destilat yang bebas $\mathrm{CO}_{2}$. Filtrat dan air bilasan digabung lalu dititrasi secara potensiometri dengan larutan standar 0,5 $\mathrm{M} \mathrm{HCl} \mathrm{hingga} \mathrm{pH} 8,4$.

Penetapan kandungan gugus karboksilat, $100 \mathrm{mg}$ humin dimasukkan ke dalam erlenmeyer dan ditambahkan $10 \mathrm{~mL}$ larutan $\mathrm{Mg}\left(\mathrm{CH}_{3} \mathrm{COO}\right)_{2} \quad 0,5 \mathrm{M}$ dan $40 \mathrm{~mL}$ air destilat yang bebas $\mathrm{CO}_{2}$. kemudian digojog dengan bantuan shaker selama 24 jam pada temperatur kamar. Lakukan juga untuk larutan blangko. Filtrat dan air bilasan digabung dan dititrasi secara potensiometri dengan larutan standar 0,1 $\mathrm{M} \mathrm{NaOH}$ hingga $\mathrm{pH}$ 9,8. Penetapan kandungan gugus $-\mathrm{OH}$ fenolat dilakukan dengan rumus :

$\mathrm{OH}$ fenol = keasaman total - kandungan $\mathrm{COOH}$

Studi adsorpsi ion logam $\mathrm{Cu}(\mathrm{II})$ pada humin

\section{Pengaruh Penambahan humin terhadap kelarutan ion logam dalam berbagai keasaman medium.}

Sebanyak $25 \mathrm{~mL}$ larutan $\mathrm{Cu}(\mathrm{II})$ dengan konsentrasi $100 \mathrm{mg} / \mathrm{L}$ dibuat dari larutan induk. Kemudian $\mathrm{pH}$ diatur dengan penambahan $\mathrm{HCl}$ atau $\mathrm{NaOH}$ sehingga mendapatkan nilai $\mathrm{pH}$ awal 2,0; 3,0; 4,0; 5,$0 ; 6,0 ; 7,0 ; 8,0 ; 9,0 ; 10 ; 11$; dan 12 . Larutan yang telah diatur pH-nya kemudian ditambahkan humin ukuran 200 mesh sebanyak $50 \mathrm{mg}$ dan digojog selama 120 menit dan didiamkan selama 24 jam untuk mencapai kesetimbangan.

\section{Penetapan tetapan laju adsorpsi pada medium air.}

Sebanyak masing masing $50 \mathrm{mg}$ humin diinteraksikan dengan $25 \mathrm{~mL}$ larutan logam $\mathrm{Cu}(\mathrm{II})$ dan $\mathrm{Cd}(\mathrm{II})$ secara individual dengan konsentrasi awal larutan logam 100 mg/L. Campuran diinteraksikan dengan cara digojog dengan bantuan shaker pada variasi waktu $2,5,10,20,40$, 90, 180, dan 200 menit. Selesai interaksi filtrat dan endapan dipisahkan dengan disaring, lalu fitran dianalisis dengan AAS. 


\section{Mekanisme interaksi dalam medium air \\ Sebanyak masing-masing 0,5} gram humin diinteraksikan dengan $25 \mathrm{~mL}$ larutan logam $\mathrm{Cu}(\mathrm{II}) 100 \mathrm{mg} / \mathrm{L}$. Shaker selama 1 jam dan didiamkan selama 24 jam. Endapan dilarutkan dalam $25 \mathrm{~mL}$ akuabides dan diekstraksi selama 30 menit (Mekanisme Pemerangkapan), residu dari atas diekstraksi dengan $25 \mathrm{~mL}$ $\mathrm{CH}_{3} \mathrm{COONa} 1 \mathrm{M}$ pada $\mathrm{pH} 8,2$ selama 2 jam kemudian disaring (Pertukaran ion lemah), residu yang didapat diekstraksi dengan $25 \mathrm{~mL} \mathrm{CH}_{3} \mathrm{COONH}_{4} 1 \mathrm{M}$ selama 5 jam, kemudian disaring (pertukaran ion kuat). Residu diekstraksi dengan $25 \mathrm{~mL}$ $0,3 \mathrm{M} \mathrm{NH}_{2} \mathrm{OH} . \mathrm{HCl}$ dalam $25 \%$ (v/v) $\mathrm{CH}_{3} \mathrm{COOH}$ selama 30 menit, kemudian disaring (Mekanisme pembentukan ikatan hidrogen). Residu diekstraksi dengan 25 $\mathrm{mL} \mathrm{Na}_{4} \mathrm{P}_{2} \mathrm{O}_{7}$ 0,1 M selama 16 jam, kemudian disaring (Mekanisme pembentukan kompleks).

\section{Penetapan energi dan kapasitas adsorpsi pada medium air}

Sebanyak $50 \quad \mathrm{mg}$ humin diinteraksikan dengan $25 \mathrm{~mL}$ larutan logam $\mathrm{Cu}(\mathrm{II})$ dengan variasi konsentrasi larutan logam 20, 40, 60, 80, 140, 180, dan $200 \mathrm{mg} / \mathrm{L}$. Campuran diinteraksikan dengan cara digojog dengan bantuan shaker selama 2 jam, kemudian didiamkan selama 24 jam. Disaring, filtrat dianalisis dengan AAS.

\section{HASIL PEMBAHASAN}

\section{Komposisi Gugus Fungsional Humin}

\section{Kualitatif}

Gambar.1 menyajikan spektra

FTIR humin hasil isolasi baik sebelum ataupun sesudah pemurnian .

Gugus $-\mathrm{OH}$ fenolat ataupun $-\mathrm{OH}$ alkoholat terlihat pada pita serapan dengan bilangan gelombang $3421,5 \mathrm{~cm}^{-1}$ yang berasal dari vibrasi ulur $-\mathrm{OH}$, bilangan gelombang 2918,1 $\mathrm{cm}^{-1}$ dan $2850 \mathrm{~cm}^{-1}$ merupakan vibrasi ulur $\mathrm{C}-\mathrm{H}$ alifatik.

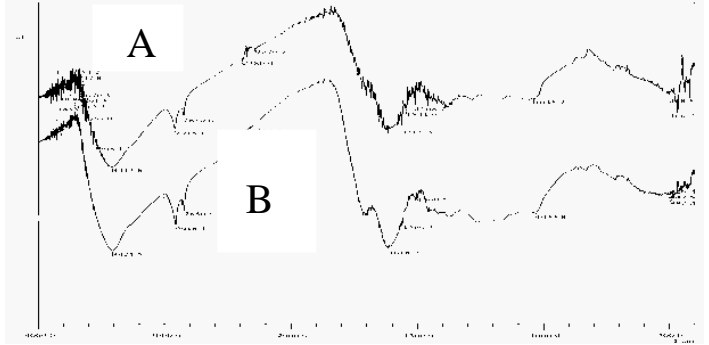

Gambar 1.Spekta inframerah A) Humin Sebelum dimurnikan B) Humin setelah dimurnikan

Gugus - $\mathrm{COOH}$ dapat terlihat pada pita serapan yang cukup jelas dengan bilangan gelombang sekitar $1700 \mathrm{~cm}^{-1}$ yang berasal dari vibrasi ulur ulur $\mathrm{C}-\mathrm{O}$ dari karboksilat. Bilangan gelombang ini khas untuk $\mathrm{C}=\mathrm{O}$ dari gugus karboksilat akibat keterlibatan resonansi gugus $-\mathrm{C}=\mathrm{O}$ dalam - $\mathrm{COOH}$. Lemahnya serapan ini mengindikasikan kecilnya kandungan $\mathrm{COOH}$ dalam humin hasil isolasi. Bilangan gelombang 1618,2 $\mathrm{cm}^{-1}$ diperkirakan merupakan vibrasi ulur $\mathrm{C}=\mathrm{C}$ aromatic atau $\mathrm{H}$ yang terikat pada $\mathrm{C}=\mathrm{O}$ (keton terkonjugasi). Selain itu juga spektra inframerah pada humin setelah melalui tahap pemurnian menunjukkan serapan pada bilangan gelombang 1164,9 $\mathrm{cm}^{-1}$ yang berasal dari vibrasi ulur $\mathrm{C}-\mathrm{O}$ dari gugus karboksilat. Dengan demikian dapat dinyatakan bahwa gugus $-\mathrm{COOH}$ dan $-\mathrm{OH}$ fenolat memang terdapat pada humin hasil isolasi.

\section{Kuantitatif}

Tabel 1 menyajikan komposisi kuantitatif gugus fungsional pada humin hasil isolasi dilakukan dengan menggunakan metode titrasi potensiometri.

Tabel 1. Komposisi kuantitatif gugus Fungsional

\begin{tabular}{|l|c|}
\hline \multicolumn{1}{|c|}{ Gugus Fungsional } & $\begin{array}{c}\text { Kandungan } \\
\text { (cmol/kg) dalam } \\
\text { humin }\end{array}$ \\
\hline Keasaman total & 677 \\
Karboksilat (-COOH) & 115 \\
Hidroksi (-OH fenolat) & 562 \\
\hline
\end{tabular}


Efektivitas proses pemurnian akan makin tinggi apabila makin banyak mineral yang hilang dari humin. Mengingat abu yang dihasilkan merupakan residu proses pembakaran humin pada temperatur tinggi yang pada hakekatnya adalah mineral, maka kadar abu dapat digunakan sebagai ukuran keberhasilan suatu proses pemurnian. Makin efektif proses pemurnian, kadar abunya akan makin sedikit.

Tabel .2. Kadar abu humin sebelum dan setelah dimurnikan

\begin{tabular}{|l|c|}
\hline Tahap pemurnian & $\begin{array}{c}\text { Kadar abu dalam } \\
\%(\mathrm{~b} / \mathrm{b})\end{array}$ \\
\hline $\begin{array}{l}\text { Humin sebelum } \\
\text { dimurnikan }\end{array}$ & 5,04 \\
\hline $\begin{array}{l}\text { Humin dengan } \\
\text { pemurnian } \\
\mathrm{HF} / \mathrm{HCl}\end{array}$ & 1,58 \\
\hline
\end{tabular}

Pengaruh penambahan humin pada kelarutan $\mathrm{Cu}(\mathrm{II})$ dalam berbagai keasaman medium air

Pada medium air terjadi kesetimbangan antara $\mathrm{H}_{2} \mathrm{O}$, ion $\mathrm{H}^{+}$dan ion $\mathrm{OH}^{-}$, sesuai persamaan reaksi :

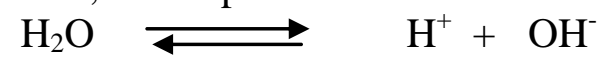

Dalam medium air, ion logam akan memiliki kecenderungan untuk membentuk kation terhidrat dengan $\mathrm{H}_{2} \mathrm{O}$.

Khusus untuk kation logam transisi dengan elektronegativitas yang relatif tinggi cenderung membentuk ikatan kovalen (koordinasi) dengan $\mathrm{H}_{2} \mathrm{O}$ dalam bentuk ion kompleks akuo yang larut dalam air.

Penambahan humin ke dalam medium air akan memberikan pengaruh yang cukup besar terhadap kelarutan logam. Situs aktif humin yang terdiri atas gugus $\quad \ni-\mathrm{COOH}$ dan $\ni-\mathrm{OH}$ fenolat dalam medium air akan terhidrolisis menurut persamaan :
Э- $\mathrm{COOH}+\mathrm{H}_{2} \mathrm{O}$

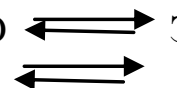
Э $-\mathrm{COO}^{-}+\mathrm{H}_{3} \mathrm{O}^{+}$
Э $-\mathrm{OH}+\mathrm{H}_{2} \mathrm{O}$ $\ni-\mathrm{O}^{-}+\mathrm{H}_{3} \mathrm{O}^{+}$

Pada keasaman medium sangat rendah situs aktif humin akan mengalami protonasi menurut persamaan :

Э- $\mathrm{COOH}+\mathrm{H}^{+} \longrightarrow \ni-\mathrm{COOH}_{2}^{+}$

Э $-\mathrm{OH}+\mathrm{H}^{+} \longrightarrow{ }^{-}-\mathrm{OH}_{2}^{+}$

Pada media dengan keasaman yang tinggi, peningkatan konsentrasi ion $\mathrm{OH}^{-}$ menyebabkan terjadinya kompetisi antara situs aktif humin ( $Э-\mathrm{COO}^{-}$dan $Э-\mathrm{O}^{-}$) dan ion $\mathrm{OH}^{-}$dalam mengikat ion logam. Mengingat ion hidroksida $\left(\mathrm{OH}^{-}\right)$ merupakan ligan yang lebih kuat daripada gugus karboksilat $\left(\Im^{-} \mathrm{COO}^{-}\right)$dan gugus hidroksi fenolat $\left(\ni^{-} \mathrm{O}^{-}\right)$, pada $\mathrm{pH}$ yang relatif tinggi interaksi antara ion hidroksida dan ion logam membentuk hidroksida logam akan dominan.

\section{Kelarutan logam $\mathrm{Cu}$ (II)}

Gambar 2 menyajikan hasil eksperimen tentang pengaruh penambahan humin pada kelarutan ion $\mathrm{Cu}(\mathrm{II})$ pada berbagai $\mathrm{pH}$.

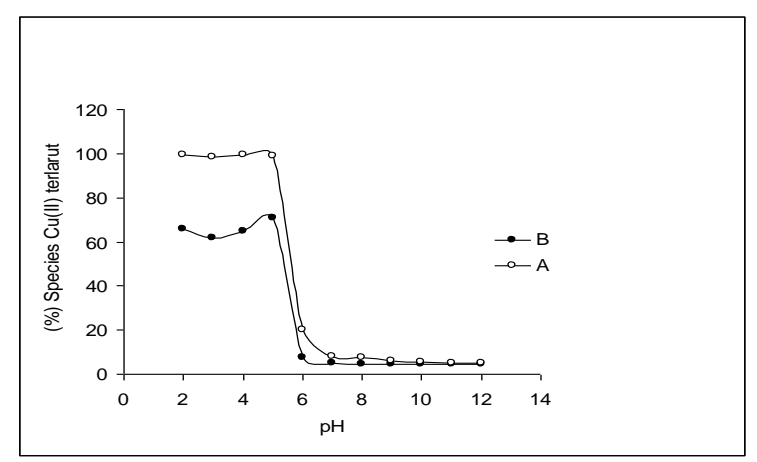

Gambar 2. Kelarutan $\mathrm{Cu}(\mathrm{II})$ dalam media air pada berbagai $\mathrm{pH}$ (A) Tanpa humin (B) Penambahan humin $50 \mathrm{mg}$

Data gambar 2(A) menunjukkan bahwa tanpa penambahan humin, semua $\mathrm{Cu}$ (II) larut dalam media air dengan $\mathrm{pH} \leq$ 5. Pada $6<\mathrm{pH}>7$, hanya sebagian kecil (8\%) $\mathrm{Cu}$ (II) yang terlarut dalam medium air. Pada $\mathrm{pH}>7$ tidak terdeteksi adanya $\mathrm{Cu}(\mathrm{II})$ yang terlarut. Gejala ini dapat diterangkan sebagai berikut :

1. Pada $\mathrm{pH} \leq 5$, ion logam $\mathrm{Cu}$ (II) dalam air terdapat dalam bentuk kation bebas dan / atau ion ion kompleks $\left[\mathrm{Cu}\left(\mathrm{H}_{2} \mathrm{O}\right)_{4}\right]^{2+}$ yang larut dalam air. 
2. Mengingat $\mathrm{Ksp} \mathrm{Cu}(\mathrm{OH})_{2}=\left[\mathrm{Cu}^{2+}\right]$ $\left[\mathrm{OH}^{-}\right]^{2}=\left[\mathrm{Cu}^{2+}\right]\left[\mathrm{Kw} /\left[\mathrm{H}^{+}\right]\right]^{2}=2,6 \mathrm{x}$ $10^{-19}$ dengan asumsi $\mathrm{Kw}=10^{-14}$, maka secara teoritis pada $\mathrm{pH} \geq 5,23$, mengingat larutan yang mengandung $\mathrm{Cu}$ (II) $100 \mathrm{mg} / \mathrm{L}$ akan mengendap sebagai $\mathrm{Cu}(\mathrm{OH})_{2}$. Hal ini dapat terlihat jelas dari gambar 2(A) bahwa jumLah $\mathrm{Cu}(\mathrm{II})$ yang terlarut berkurang secara drastis pada $5<\mathrm{pH}$ $>7$. Pada $\mathrm{pH}>7$ semua logam $\mathrm{Cu}($ II) telah mengendap sebagai $\mathrm{Cu}(\mathrm{OH})_{2}$.

Kecuali untuk $2<\mathrm{pH}<6$, data pada Gambar 2(B) memperlihatkan pola yang hampir sama dengan Gambar 2(A). Hal ini menegaskan bahwa penambahan humin ke dalam larutan tidak terlalu mempengaruhi kelarutan $\mathrm{Cu}(\mathrm{II})$. Pada $2<$ $\mathrm{pH}<6$, situs aktif humin terdapat dalam bentuk Э - $\mathrm{COO}^{-}$dan $Э-\mathrm{OH}$ (Narsito et.al, 2004) sehingga rendahnya kelarutan $\mathrm{Cu}$ (II) pada $\mathrm{pH}$ tersebut terutama sebagai akibat adsorpsi $\mathrm{Cu}(\mathrm{II})$ pada humin dengan memanfaatkan gugus $Э$ - $\mathrm{COO}^{-}$.

\section{Karakteristik Kinetika adsorpsi $\mathrm{Cu}(\mathrm{II})$} pada humin dalam media air tawar

\section{Aspek Kinetika}

Laju adsorpsi. Kajian ini bertujuan untuk menetapkan konstanta laju adsorpsi yang memberikan informasi seberapa cepat proses adsorpsi tersebut. Selain itu juga akan diketahui waktu yang dibutuhkan interaksi antara $\mathrm{Cu}$ (II) dengan humin untuk mencapai kondisi kesetimbangan.

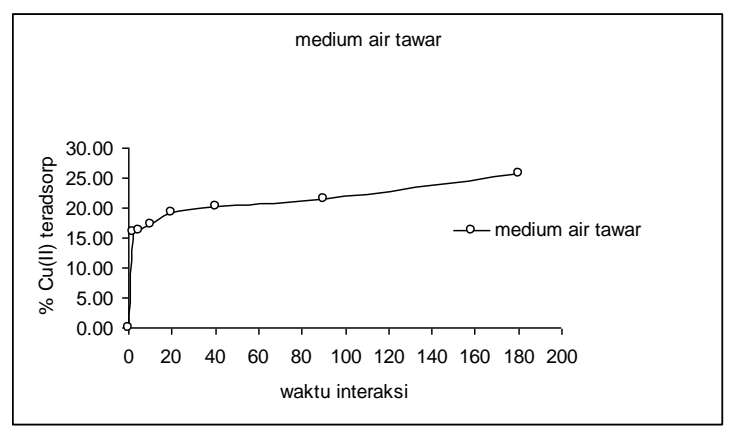

Gambar 3. Pengaruh waktu terhadap adsorpsi logam $\mathrm{Cu}(\mathrm{II})$ pada humin
Gambar 3 menyajikan hasil eksperimen pengaruh waktu terhadap \% $\mathrm{Cu}(\mathrm{II})$ yang teradsorpsi pada humin sebagai adsorben dalam media air tawar.

Hasil eksperimen pada Gambar 3 menunjukkan bahwa proses adsorpsi $\mathrm{Cu}$ (II) pada humin terjadi cukup cepat. Pada 2 menit pertama telah terjadi proses adsorpsi $\mathrm{Cu}$ (II) dalam medium air tawar dan sebesar $16 \%$.

Berdasarkan stabilitasnya, dalam medium air tawar $\mathrm{Cu}$ (II) cenderung terdapat dalam bentuk kompleks $\left[\mathrm{Cu}\left(\mathrm{H}_{2} \mathrm{O}\right)_{4}\right]^{2+}$ dan $\mathrm{CuCl}^{+}$. Kedua spesies ini bertanggung jawab dalam proses adsorpsi logam $\mathrm{Cu}(\mathrm{II})$ pada humin. Dengan demikian dapat dinyatakan bahwa selama adsorpsi pada humin berlangsung, adsorpsi $\mathrm{Cu}(\mathrm{II})$ sebagai $\mathrm{CuCl}^{+}$lebih dominan dari pada sebagai $\left[\mathrm{Cu}\left(\mathrm{H}_{2} \mathrm{O}\right)_{4}\right]^{2+}$.

Tabel 3 menyajikan hasil perhitungan nilai konstanta adsorpsi berdasarkan data dalam Gambar 3 dengan metode perhitungan usulan Santosa (2001) sebagai pengembangan model kinetika Langmuir-Hinshelwood. Dalam metode tersebut nilai konstanta laju adsorpsi diperoleh sebagai nilai slope dari kurva linear $\ln (\mathrm{Co} / \mathrm{C}) / \mathrm{C}$ vs $\mathrm{t} / \mathrm{C}$.

Tabel 3 Parameter kinetika adsorpsi $\mathrm{Cu}$ (II) pada humin dalam media air tawar.

\begin{tabular}{|c|c|}
\hline \multicolumn{2}{|c|}{$\mathrm{k}_{\text {ads }}\left(\right.$ menit $\left.^{-1}\right)$} \\
\hline fase cepat & fase lambat \\
\hline $2,7 \times 10^{-3}$ & $0,6 \times 10^{-3}$ \\
$\left(\mathrm{R}^{2}=0,994\right)$ & $\left(\mathrm{R}^{2}=0,983\right)$ \\
\hline
\end{tabular}

Dalam penelitian ini teramati bahwa plot $\ln (\mathrm{Co} / \mathrm{C}) / \mathrm{C}$ vs $\mathrm{t} / \mathrm{C}$ memberikan kurva Bi-phasic, yang mengindikasikan keterlibatan dua proses adsorpsi parallel dengan kinetika yang berbeda yaitu proses adsorpsi cepat dan proses adsorpsi lambat. Data dalam tabel 3 menunjukkan bahwa adsorpsi $\mathrm{Cu}(\mathrm{II})$ pada humin dalam medium 
air tawar berlangsung dalam dua fase yang berbeda. Sesuai dengan pernyataan sebelumnya bahwa adsorpsi $\mathrm{Cu}(\mathrm{II})$ pada humin melibatkan terutama spesies $\left[\mathrm{Cu}\left(\mathrm{H}_{2} \mathrm{O}\right)_{4}\right]^{2+}$ dan $\mathrm{CuCl}^{+}$. Spesies $\mathrm{CuCl}^{+}$ teradsorpsi lebih cepat daripada spesies $\left[\mathrm{Cu}\left(\mathrm{H}_{2} \mathrm{O}\right)_{4}\right]^{2+}$.

Mekanisme adsorpsi. Mekanisme adsorpsi yang terjadi pada adsorpsi $\mathrm{Cu}$ (II) pada humin ditentukan dengan menggunakan proses desorpsi secara ekstraksi sekuensial. Proses ekstraksi menggunakan pelarut secara bertahap untuk mengetahui apakah adsorpsi logam $\mathrm{Cu}$ (II) pada humin melibatkan adsorpsi secara fisika dan adsorpsi secara kimia.

Tabel 4 menyajikan data hasil proses ekstraksi sekuensial terhadap humin yang telah diinteraksikan dengan logam $\mathrm{Cu}(\mathrm{II})$ dalam medium air tawar.

Tabel 4 Kontribusi mekanisme interaksi logam $\mathrm{Cu}$ (II) dengan humin

\begin{tabular}{|c|l|c|}
\hline No & \multicolumn{1}{|c|}{ Mekanisme } & $\begin{array}{c}\text { Kontribusi } \\
(\%)\end{array}$ \\
\hline 1 & Pemerangkapan & 0.58 \\
2 & Pertukaran ion & \\
& a. Lemah & 0.58 \\
& b. Kuat & 8.77 \\
3 & Pembentukan & 43.86 \\
4 & ikatan hidrogen & Pembentukan \\
kompleks & 46.20 \\
\hline
\end{tabular}

Pada Tabel 4 tersaji bahwa pada proses adsorpsi logam $\mathrm{Cu}$ (II) pada humin didominasi oleh adsorpsi kimia. Hal ini dapat dilihat dari \% kontribusi adsorpsi melalui mekanisme reaksi pemerangkapan yang jauh lebih sedikit daripada mekanisme lainnya.

Dari Tabel 4 mekanisme adsorpsi logam $\mathrm{Cu}$ (II) pada humin dalam medium air tawar didominasi oleh pembentukan ikatan hidrogen dan ikatan kompleks. Hal ini mengindikasikan bahwa pada medium air tawar sebagian besar $\mathrm{Cu}(\mathrm{II})$ berada dalam spesies $\left[\mathrm{Cu}\left(\mathrm{H}_{2} \mathrm{O}\right)_{4}\right]^{2+}$ yang cenderung membentuk ikatan hidrogen dengan situs aktif humin. Sifat $\mathrm{Cu}$ (II) yang relatif keras menyebabkan $\mathrm{Cu}(\mathrm{II})$ cocok berinteraksi secara kompleks dengan situs aktif pada humin yang bersifat keras dan berada dalam bentuk $-\mathrm{COOH}$.

Mekanisme pemerangkapan terjadi pada saat molekul adsorbat ( logam-logam) terperangkap didalam adsorben (humin). Proses ini tidak melibatkan interaksi kimia atau tidak terjadi perubahan sifat kimia dari masing-masing komponen. Logam yang terperangkap akan mudah sekali untuk dilepaskan, tanpa menggunakan reagen-reagen tertentu. Dari tabel 4, terlihat bahwa jumLah logam $\mathrm{Cu}$ (II) yang terperangkap sangat kecil. Hal ini disebabkan karena $\mathrm{Cu}$ (II) dan dalam media air membentuk kompleks $\mathrm{H}_{2} \mathrm{O}$. Kompleks $\mathrm{H}_{2} \mathrm{O}$ yang terbentuk memiliki ukuran yang cukup besar sehingga kemampuan untuk terperangkap pada humin menjadi kecil.

Mekanisme pertukaran kation berlangsung ketika terjadi pertukaran kation yang terdapat pada humin dengan logam yang bermuatan. Gambar 4 menyajikan perkiraan mekanisme pertukaran kation. Pada mekanisme ini terjadi pertukaran kation $\mathrm{Cu}(\mathrm{II})$, menggantikan posisi kation $\mathrm{Na}(\mathrm{I})$

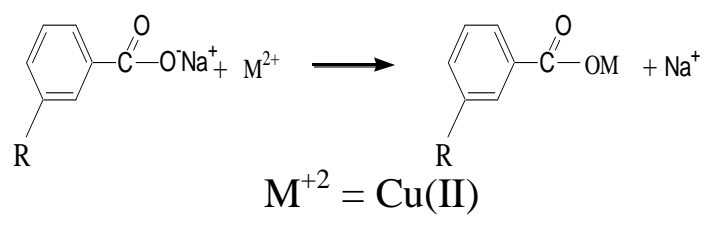

Gambar 4. Mekanisme pertukaran kation antara $\mathrm{Na}^{+}$dengan $\mathrm{Cu}$ (II) yang teradsorpsi pada humin

Mekanisme pertukaran kation ini terjadi antara kation logam pada adsorben humin yang melibatkan situs aktifnya yaitu gugus Э-COONa dan Э-ONa fenolat digantikan oleh kation $\mathrm{Cu}(\mathrm{II})$.

Mekanisme pembentukan ikatan hidrogen memberikan peran yang sangat besar, karena logam $\mathrm{Cu}$ (II) berada dalam keadaan terkomplekskan dengan $\mathrm{H}_{2} \mathrm{O}$. 
Ikatan hidrogen terjadi antara dua atom yang memiliki elektronegatifitas yang tinggi dengan hidrogen yang bersifat protonik. Oleh sebab itu adsorpsi logam $\mathrm{Cu}$ (II) pada humin dalam medium air tawar mekanisme pembentukan ikatan hidrogen memberikan kontribusi terbesar. Mekanisme yang terjadi dapat diperkirakan seperti pada Gambar 5 berikut

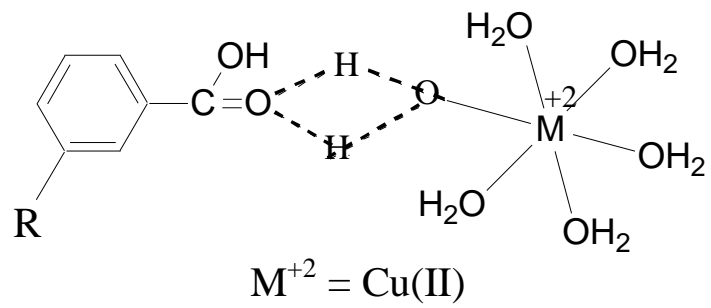

Gambar 5 Perkiraan mekanisme pembantukan ikatan hidrogen

Mekanisme pembentukan senyawa komplek antara logam $\mathrm{Cu}(\mathrm{II})$ dengan humin sangat mungkin terjadi, namun relatif kecil jika dibandingkan dengan mekanisme sebelumnya karena logam $\mathrm{Cu}$ (II) berada dalam keadaan kompleks dengan $\mathrm{H}_{2} \mathrm{O}$. Kompleks $\mathrm{H}_{2} \mathrm{O}$ ini memiliki ukuran yang relatif besar sehingga dapat menghalangi terbentuknya kompleks dengan situs aktif pada humin.

Kompleks yang terbentuk antara logam $\mathrm{Cu}(\mathrm{II})$ terhidrat dengan gugus $Э$ $\mathrm{COO}^{-}$dari humin dapat terjadi dengan 2 kemungkinan. Pertama, kation logam $\mathrm{Cu}$ (II) bertindak sebagai atom pusat (akseptor pasangan electron) membentuk ikatan koordinasi dengan gugus $Э-\mathrm{COO}^{-}$ pada humin yang bertindak sebagai ligan (donor pasangan electron). Kedua, kation logam $\mathrm{Cu}(\mathrm{II})$ membentuk kompleks dengan struktur cincin khelat yang menghasilkan ikatan yang menghasilkan ikatan yang sangat kuat. Ikatan ini hanya dapat didesorpsi dengan agen pengkhelat.
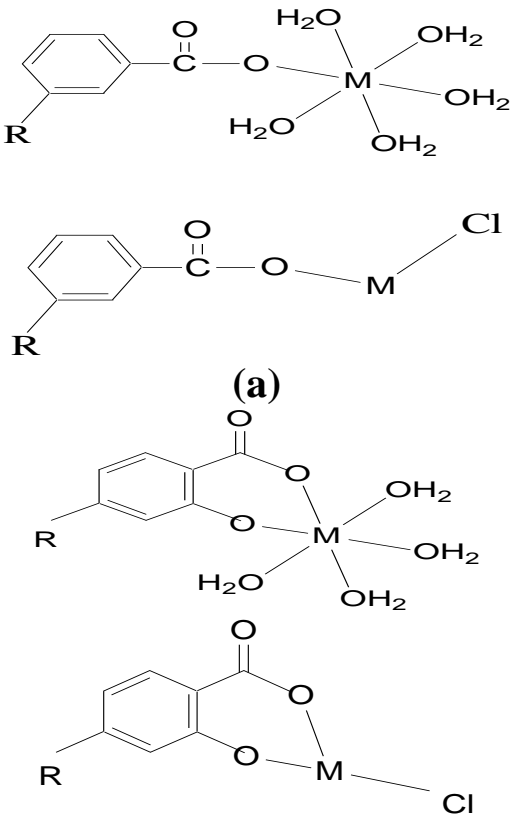

(b)

$\mathrm{M}=\mathrm{Cu}(\mathrm{II})$

Gambar 6.Mekanisme usulan untuk Pembentukan kompleks $\mathrm{Cu}(\mathrm{II})-\quad \operatorname{Humin}(\mathrm{a})$ ikatan koordinasi, (b) struktur cincin khelat

\section{Aspek Termodinamika}

Pola isoterm adsorpsi ditunjukkan dengan membuat kurva jumLah ion logam teradsorp per gram adsorben terhadap konsentrasi awal benomil. Hal ini dipelajari dengan memvariasikan konsentrasi awal logam $\mathrm{Cu}(\mathrm{II})$ kemudian masing-masing logam tersaebut diinteraksikan dengan humin selama 120 menit.

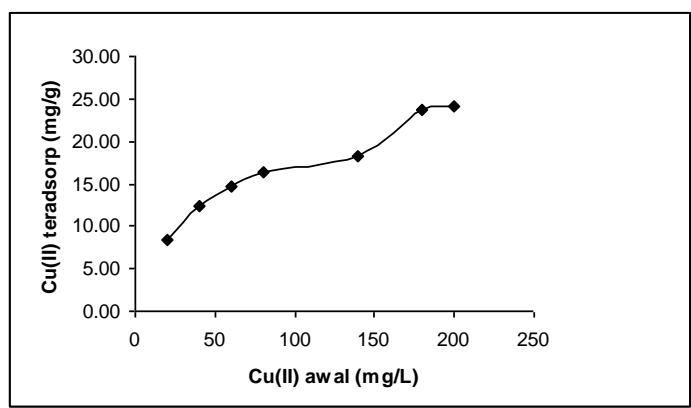

Gambar 7. Pola isoterm adsorpsi logam $\mathrm{Cu}$ (II) pada humin dalam medium air tawar 
Pola isoterm adsorpsi yang tersaji pada gambar 7 menunjukkan bahwa kenaikan jumLah $\mathrm{Cu}(\mathrm{II})$ yang teradsorpsi per gram adsorben berbanding lurus dengan konsentrasi $\mathrm{Cu}$ (II) awal yang diinteraksikan pada humin. Namun pada konsentrasi awal yang cukup besar (80$200 \mathrm{mg} / \mathrm{L}$ ) jumLah logam $\mathrm{Cu}(\mathrm{II})$ yang teradsorp naik secara perlahan. Pada medium air tawar, terjadi kenaikan secara perlahan dari konsentrasi awal yang rendah sampai konsentrasi yang besar dan akhirnya.

Untuk mengevaluasi sifat adsorpsi yang terjadi, digunakan persaman linier isoterm adsorpsi Langmuir dan persamaan isoterm freundlich. Hasil keduanya akan diperbandingkan sehingga akan diperoleh suatu kesimpulan pola yang mana yang paling sesuai untuk proses isoterm logam $\mathrm{Cu}$ (II) pada humin dalam medium air tawar.

Persaman linier isoterm adsorpsi Langmuir yaitu dengan membuat grafik $\mathrm{Ca} / \mathrm{m}$ versus $\mathrm{Ca}$. Penerapkan persamaan isoterm Langmuir digunakan untuk mengetahui harga kapasitas adsorpsi (b) dan konstanta kesetimbangan adsorpsi (K), sedangkan besarnya energi adsorpsi selanjutnya ditentukan menurut persamaan $\mathrm{E}=\mathrm{RT} \ln \mathrm{K}$. Nilai isoterm adsorpsi model Langmuir logam $\mathrm{Cu}$ (II) pada humin tersaji pada tabel 5 .

Tabel 5. Parameter isoterm adsorpsi Langmuir untuk logam $\mathrm{Cu}(\mathrm{II})$

\begin{tabular}{|c|c|c|c|}
\hline \multicolumn{4}{|c|}{ Parameter isoterm adsorpsi Langmuir } \\
\hline $\begin{array}{l}\mathrm{b} \\
(\mathrm{mol} / \mathrm{g})\end{array}$ & $\begin{array}{l}\mathrm{K} \\
(\mathrm{mol} / \mathrm{L})^{-1}\end{array}$ & $\begin{array}{l}\mathrm{E} \\
(\mathrm{kJ} / \mathrm{mol})\end{array}$ & $\mathrm{R}^{2}$ \\
\hline $\begin{array}{l}3,033 \mathrm{x} \\
10^{-4}\end{array}$ & $\begin{array}{l}8,517 \quad x \\
10^{+3}\end{array}$ & 22,57 & 0,997 \\
\hline
\end{tabular}

Berdasarkan tabel 5, terlihat bahwa besarnya energi adsorpsi logam $\mathrm{Cu}$ (II) pada humin dalam medium air tawar sebesar 22,57 kJ/mol. Data ini menjelaskan bahwa adsorpsi logam
$\mathrm{Cu}$ (II) pada humin dalam media air tawar melibatkan proses kemisorpsi.

Tabel 6. Parameter isoterm adsorpsi

Freundlich logam $\mathrm{Cu}$ (II)

\begin{tabular}{|l|l|l|}
\hline \multicolumn{3}{|c|}{ Parameter isoterm adsorpsi Freundlich } \\
\hline $1 / \mathrm{n}$ & $\mathrm{K}(\mathrm{mol} / \mathrm{L})^{-1}$ & $\mathrm{R}^{2}$ \\
\hline 0,2655 & $1,77 \times 10^{+3}$ & 0,968 \\
\hline
\end{tabular}

Data yang diperoleh pada isoterm adsorpsi Freundlich jika dibandingkan dengan isoterm adsorpsi Langmuir terlihat bahwa adsorpsi logam $\mathrm{Cu}(\mathrm{II})$ pada humin dalam medium air tawar lebih sesuai mengikuti model isoterm langmuir. Hal ini dapat dilihat dari nilai $\mathrm{R}^{2}$ pada masingmasing model yang menunjukkan nilai kesesuaian (degree of fitness). Dengan demikian dapat ditegaskan bahwa adsorpsi logam $\mathrm{Cu}$ (II) pada humin berlangsung dengan model isoterm Langmuir yang menunjukkan prosesnya berlangsung secara monolayer. Kemungkinan yang terjadi adalah situs-situs aktif pada permukaan adsorben HA didominasi oleh gugus fungsi berupa $-\mathrm{COOH}$ dan $-\mathrm{OH}$ fenolat.

\section{KESIMPULAN}

1. Gugus fungsional utama humin yang terlibat dalam proses adsorpsi logam $\mathrm{Cu}(\mathrm{II})$ adalah $-\mathrm{COOH}$ dan $-\mathrm{OH}$ fenolat. Humin yang diperoleh mengandung gugus $-\mathrm{COOH}$ sebesar $115 \mathrm{cmol} / \mathrm{kg}$ dan gugus $-\mathrm{OH}$ fenolat sebesar 562 $\mathrm{cmol} / \mathrm{kg}$.

2. Proses adsorpsi logam $\mathrm{Cu}(\mathrm{II})$ pada humin dalam medium air tawar dan terutama ditentukan oleh dua spesies yaitu $\left[\mathrm{Cu}\left(\mathrm{H}_{2} \mathrm{O}\right)_{4}\right]^{2+}$

3. Adsorpsi logam $\mathrm{Cu}(\mathrm{II})$ dan $\mathrm{Cd}(\mathrm{II})$ pada humin dalam medium air tawar dan air laut berlangsung dengan model isoterm Langmuir yang menunjukkan prosesnya berlangsung secara monolayer. 


\section{DAFTAR PUSTAKA}

Adamson, A. W., 1990, "Physical Chemistry of Surface", $5^{\text {th }}$ edition, John Willey and Sons, Toronto.

Gafney, S.J., Marley, N.A., dan Clark, S.B., 1996, Humus and Fulfic Acid and Organic Colloidal Material in the Enviromental (dalam Gaffney, J.S., dkk., 1996, "Humic and Fulfic Acid: Isolation, Structure and Enviromental Role"), American Chemical Society, Washington.

Hayes, M. H. B., dan Himes, F.L., 1986, "Nature and Properties of HumusMineral Complexes", In ; "Interactions of Soil Mineral With Natural Organics and Microbes" (P.M. Huang and M. Schnitzer, eds), Soil Sci. Soc. Am. Special Publ., 17, Soil Sci. Soc. Am, Madison, WI; 103-158.

Megan, B Kogut, dan Bettina M. Voelker, 2001, Strong Copper-Binding of Terrestrial Humic Substances in Seawater, "Enviromental Science and Technology", 35, 1149-1156.
Mohadi, S, 2004, "Immobilisasi Asam Humat pada Kitin dan Aplikasinya untuk Adsorpsi Ag(I) dalam Medium Air", Tesis, Program Pascasarjana, Universitas Gadjah Mada., Yogyakarta.

Santosa, S.J., Narsito., dan Lesbani, 2001, "The Determination of Active Site, Capasity, Energy, and Rate Constan on the Adsorption of $\mathrm{Zn}$ (II) and Cd (II) on Citin", J.Ion Echange, 14, 8992.

Tan, K. H., 1998, "Dasar-dasar Kimia Tanah" (diterjemahkan oleh Goenadi, D.H., dan Radjagukguk, D), Gadjah Mada University Press, Yogyakarta. 